\title{
Legal discretion in criminal law: general theoretic and branch-wise aspects
}

\author{
Aleksandr Aleksandrovich Nikitin* \\ ${ }^{1}$ Saratov State Law Academy, Department of Prosecutor's Supervision and Criminology, Saratov, \\ Russia
}

\begin{abstract}
Pre-requisites: legal discretion in criminal law just as in other branches has only partially been a subject matter of legal analysis. Predominantly, a law-enforcement type of discretion was studied, which is implemented by law-enforcement authorities during criminal prosecution. However, modern surveys in the field of law theory consider discretion as a general law phenomenon including law-enforcement, law-making, and lawinterpretation aspects. This suggests the need to study legal discretion in criminal law from new points of view. Moreover, one should also take into account a dual-aspect nature of legal discretion, e.g., a combination of characteristics of the subject implementing discretion and law-regulated relations where this takes place. The research objective is to define an opportunity of affecting subjects implementing individual types of legal discretion (law-enforcement, law-making, and law-interpretation) intended for optimization of the discretion level in criminal law. Methods: a combination of common, general scientific, specific scientific, and specific legal methods. First of all, the paper uses a systemic and functional approach. Results. Legal discretion in legal law is represented by lawenforcement, law-making, and law-interpretation discretion of respective subjects. These types of discretion are interdependent and indissolubly related. Currently, an integrated approach to studying these types of discretions in legal law is poorly discussed in literature. Meanwhile, only this approach allows for a systematic study of legal discretion limits (in general and for individual types) and for adequate evaluation of their efficiency in criminal law.
\end{abstract}

Keywords: legal discretion, law-making, application of law, legal interpretation

\section{Introduction}

Discretion in law is a phenomenon causing a growing interest of representatives of legal science. Initially, researchers turned their attention to discretion realized by the subject implementing law-enforcement functions - by an administrative or judicial authority. In particular, Barak has studied the issues of judicial discretion in his comprehensive monographs [1] while Rarog and Gracheva paid attention to individual issues of limiting judicial discretion [2], and Antropov analyzed law-enforcement discretion [3]. While this

*Corresponding author: alexnik-82@mail.ru 
aspect of legal discretion has been drawing the attention of scientists for quite a long period, its research remains relevant. New papers of Russian and foreign authors are still published, which are dedicated to the discretion of administrative authorities [4] and tools to control such discretion [5], judicial discretion [6], limits of discretion in the execution of court orders [7], and other issues of law enforcement discretion.

Research results of these issues within branch legal sciences demonstrated a clear demand for their systematization and further scientific surveys in the theory of state and law. Abstracting from branch issues showed an imbalance in studying legal discretion - other areas of legal activity except for law enforcement were poorly studied in a respective aspect [8]. Meanwhile, legal discretion in law-making and law-interpretation practice is expressed to the same extent as in law enforcement, which allows distinguishing respective types of legal discretion: law-making and law-interpretation. One can see that along with classical studies of discretion in law application, there are papers dedicated to issues of discretion during the judicial interpretation of legal norms [9] of law-making discretion. In particular, the researchers propose two approaches to this issue: a conventional approach limiting lawmaking discretion by resolutions of legislative bodies and a holistic approach referred to lawmaking discretion of a resolution and other bodies taking part in the adoption of legal acts and affecting it [10].

This general theoretic complex approach to legal discretion must be extended to criminal law. It will allow for studying and interpreting criminal norms through the prism of legal discretion and for a fresh look at law-making discretion in this branch of law.

This research is intended to define opportunities of affecting subjects implementing individual types of legal discretion (law-making, law-enforcement, law-interpretation) in order to optimize the level of discretion in criminal law and balance its types between each other.

\section{Methods}

A study of legal discretion as an integrated legal phenomenon and its manifestations in criminal law suggests the use of all scientific methods applied to academic research. Special attention should be paid to using systematic and functional approaches in the research. This is because legal discretion in criminal law includes three primary types of discretion: lawmaking, law-interpretation, and law-enforcement. Each type has specific features reflecting a functional purpose of various legal activities where discretion is implemented, but in their relations, they reveal the integrity of the subject of research - legal discretion.

\section{Results}

A number of conclusions can be made upon the results of the research.

First of all, law-making discretion in criminal law is implemented in solving a number of issues occurring in the creation and correction of legal norms. These, in particular, include: need of criminalization or decriminalization of any act; the degree of the public danger represented by a certain act and criminalization of a respective crime; types and amount of penalty for committing a certain crime; grounds and conditions of exemption from criminal liability or penalty, etc. In particular, the norms regulating exemption from criminal liability and penalty are a shining example of freedom of law-making discretion provided by the legislator. Most types of such exemption are of a discretion nature and allow the legislator to take a decision at its own internal discretion. A specific feature of discretion in this case is the polysubjective nature, e.g., discretion can be implemented by the judge, law-enforcement officers, agents of correctional authorities, officials of penal inspections. Taking into account 
that criminal law is a public law branch, the legislator has a sufficiently wide extent of discretion. This is because actual relations subject to public law have no stability that is present in relations governed by private legal norms (for example, family relations or contractual relations have a long-term history of development preceding the point in time when the norms governing them now were created). They can be more easily changed as per the model of relations included by the legislator into the public legal norm.

Law-making shall take into account that the specifics of governed and law-enforcement discretion have two aspects expressed in specific qualities of the law-enforcement subject and in activities governed by legal norms. Such an approach is adopted in foreign literature $[11,12]$, and understanding of discretion is, first of all, related to the solution of a practical task or respective dispute [13-16].

Second, in the interpretation of legal norms (this entails explanation beyond the lawenforcement process), interpreter discretion is implemented in selecting means of interpretation and defining those elements that are required for the correct explanation. Apart from the sense and contents of the legal norm, the interpreter shall sometimes define and explain: the true will of the legislator embedded into the legal norm; the true purpose of adopting the interpreted legal norm; the presence and nature of systemic links of such law with other laws; extra-legal factors existing at the time of adopting the interpreted legal norm. The scope of interpretation and final outcomes will depend on the interpreter's decision concerning the above matters. An example can be clarifications of the Supreme Court of the Russian Federation concerning the use of Articles 79 and 80 of the RF Criminal Code given in the Statement of the Plenary Meeting as of April 21, 2009, No. 8 On Legal Practice of Release on Parole and Substation of Unserved Portion with Milder Punishment.

Third, the law enforcer's discretion is formed by several elements - decisions taken by this subject at each stage of the law-enforcement process. It can be based on criminal legal norms and criminal procedural legal norms and, therefore, it can be present even in the realization of absolutely definite norms (containing no alternative options for actions). The legislator and interpreter (that carries out official interpretation of legal norms mandatory for the law enforcer) can limit and expand the freedom of law-enforcement discretion, but it is impossible to completely eliminate it.

These types of discretion are indissolubly connected with each other, since they are manifestations of the same phenomenon - discretion in law.

\section{Discussion}

Interaction of law-making, law-interpretation, and law-enforcement discretion is cyclic in its nature. Law-making discretion can not only define the limits of discretion for the law-maker or interpreter or affect it otherwise - a reverse effect is also possible when issues in the lawenforcement practice compel the legislator to correct the legal norm in a specific way thereby limiting the freedom of its discretion. An example is amendments to Part 1, Article 79 of the Criminal Code of the Russian Federation "Release on Parole" when the legislator excluded a discretion nature of its application and provided it with a mandatory nature by obliging the law-enforcer to use this type of release taking into account specific conditions. In a similar way, the freedom of law-making discretion can be limited by the discretion of the interpreter. In particular, this happens when the legal norm is adapted to the practice of its application formed under influence of law interpretation acts (for example, decrees of the Plenum of Supreme Court of the Russian Federation). This situation has arisen, for instance, for the institute of complicity in a crime against property. According to clarifications of the Supreme Court of the Russian Federation contained in the Plenum Decree dated December 27, 2002, No. 29 On Legal Practice in Larceny, Theft and Robbery Cases, an accomplice's actions were acknowledged to be joint participation. If a person did not enter a house but took part in 
breaking doors, locks, gratings, removed stolen items under a preliminary agreement, backed up other accomplices against possible uncovering of the crime, the criminal behavior is not joint participation and, due to Part 2, Article 34 of the RF Civil Code, requires no qualification under Article 33 of the RF Civil Code. Such interpretation changes the sense of used norms and could be taken into account by the legislator in modifying respective articles.

However, a reference point is still law-making discretion. As a part of the law-making process, the legislator takes a system of decisions expressed in adopted legal norms. By implementing own discretion, the legislator can limit or, on the contrary, expand the freedom of discretion of the interpreter (for example, by abandoning the use of complicated terminology that requires interpretation, or appraisal categories) and law enforcer (by decreasing or increasing the number of types of punishment used for commitment of a certain crime, or upper and lower limits for each of applied types of punishment, etc.). The legislator shall take into account that laws must be efficient - their use by authorized persons and authorities shall not face unjustified challenges caused by disadvantages of legal norms and excessive restrictions of law-enforcement discretion. Moreover, it is required to create conditions to realize branch principles, in particular, the principle of equity, the implementation of which is impossible without certain freedom of law-enforcement discretion.

\section{Conclusion}

Integrated study of law-making, law-interpretation, and law-enforcement discretion in criminal law as specific manifestations of the unified common-law phenomenon allows for more complete identification of links between them for assessment of a level of mutual impact of these types of discretion on each other. In its turn, this may allow the researchers to systematically analyze existing limits of each type of discretion, to determine their deficiency in terms of setting a balanced level of discretion in criminal law.

\section{References}

1. A. Barak, Sudeiskoe usmotrenie [Judicial discretion] (Norma, Moscow, 1999)

2. A.I. Rarog, Yu.V. Gracheva, State and Law 11, 93-100 (2002)

3. V.G. Antropov, Pravoprimenitelnoe usmotrenie: ponyatie i formirovanie: logikosemanticheskii aspect [Law-enforcement discretion: notion and formation: logical and semantic aspect]. Abstract of a PhD thesis in Legal Science (Volgograd Law Institute of the Ministry of Internal Affairs of Russia, Volgograd, 1995)

4. J. Heath, Administrative discretion and the rule of law, in The Machinery of Government: Public Administration and the Liberal State, 254-299 (Oxford University Press, New York, 2020). https://doi.org/10.1093/oso/9780197509616.003.0006

5. J. Neimanis, Administrative Law and Process, 4(27), 41-46 (2020). https://doi.org/10.17721//2227-796X.2019.4.04

6. E.S. Azarova, Legal Concept, 18(2), 69-73 (2019). https://doi.org/10.15688/lc.jvolsu.2019.2.10

7. P. Szczekocki, Studia Iuridica Lublinensia, 29(3), 149-162 (2020). http://dx.doi.org/10.17951/sil.2020.29.3.149-162

8. Yu.V. Onosov, Siberian Law Review, 17(1), 11-16 (2020). https://doi.org/10.19073/2658-7602-2020-17-1-11-16 
9. L. Leszczyński, Studia Iuridica Lublinensia, 29(3), 39-54 (2020). http://dx.doi.org/10.17951/sil.2020.29.3.39-54

10. T. Biernat, Studia Iuridica Lublinensia, 29(3), 67-85 (2020). http://dx.doi.org/10.17951/sil.2020.29.3.67-85

11. K.C. Davis, Discretionary justice: a preliminary inquiry (Louisiana State University Press, Baton Rouge, 1969)

12. R. Lempert, Law Soc. Rev. 24(2), 321-322 (1990). https://doi.org/10.2307/3053681

13. M. Galanter, Adjudication, litigation and related phenomena, in L. Lipson and S. Wheller (eds.), Law and the Social Sciences, 151-258 (Russel Sage Foundation, New York, 1986). https://doi.org/10.7758/9781610448833.7

14. C.E. Schneider, Discretion and rules: a lawyer's view, in K. Hawkins (ed.), The Uses of Discretion, 47-88 (Clarendon Press, Oxford, 1992)

15. A.C. Hutchinson, J.N. Wakefield, Oxf. J. Leg. Stud. 2(1), 86-110 (1986). https://doi.org/10.1093/ojls/2.1.86

16. J. Frank, Courts on trial (Princeton University Press, Princeton, 1949) 